\title{
HOMENAGEM A UM ACADÊMICO: TAUMATRÓPIO LYNNMARIANO
}

\author{
Guilherme ADAMI (FAACG, USP) ${ }^{1}$
}

Sempre implicado no que estudava (fosse cultura, literatura ou linguística), Lynn Mario nunca desviou o olhar da questão dos conflitos inerentes ao comportamento das línguas. É assim que, há décadas, ele vem ajudando aqueles que cruzam seu caminho a se construírem como pessoas mais sensíveis ao mundo atual. Os estudos sobre a situação política do Concani (na Índia); a educação para cidadania global (na Inglaterra); a escrita multimodal e sua relação com o português e a educação de povos indígenas; o ensino de inglês no tocante à ética e aos métodos; a questão do conceito de letramentos, de maneira geral; e a literatura nas aulas do sistema público de ensino (todos esses últimos no Brasil) lhe dão uma bagagem que mostra as possibilidades de um acadêmico "ser muitos".

Aliás, é marcante nele que seja um pesquisador que "revolve": remexe, arranca, gira, expõe muitos solos... estreitando o espaço entre as letras, a pedagogia, a filosofia e as ciências sociais. É um "cavador", que arranca esforçosamente os sedimentos que cobrem as raízes da terra de nossas crenças bem compactadas; ao mesmo tempo, é quem tensiona o taumatrópio e, entre uma coisa e outra, funde, em movimento, realidades opostas. Aproxima aqueles do entorno entre eles mesmos e também aproxima consigo os que mergulham com ele na trajetória do jovem periplante que percorreu Inglaterra, Moçambique, Canadá, Austrália e Brasil, seu país “sem documento".

Com esse espírito errante, não aceita - nega, rejeita, protesta - que se petrifique em um só ou que estaque, imóvel. Suas multifaces impactam o trabalho de cada (ex)orientando e além, com uma evolução singela dia-a-dia, a cada encontro do grupo de estudos, até que um salto no raciocínio surpreenda com leituras inesperadas, desconhecidas. Porque Lynn é alguém que faz seu dever de casa: vem caminhando suave, suave, com os seus, mas não vive só a Universidade. Sua produção de conhecimento ocorre fora dela - também e principalmente - e, quando traz seus frutos, traz junto um pedaço de si mesmo, que ele põe à mesa para provarmos.

\footnotetext{
${ }^{1}$ Professor na Fundação Antonio-Antonieta Cintra Gordinho (FAACG) e Doutorando pela Universidade de São Paulo (USP) no Programa de Estudos Linguísticos e Literários em Inglês. guilherme.adami@usp.br
} 